\title{
The system of local supply of stone tools in Amzabegovo-Vršnik culture from Neolithic Macedonia
}

\author{
Vasilka Dimitrovska \\ Institute of History and Archaeology, 'Goce Delčev' University, Štip, MK \\ info@arheo.com.mk
}

\begin{abstract}
Although the number of Neolithic sites excavated in the territory of the Republic of Macedonia is considerable, the stone tools pertinent to these sites are still less known because they have never interested investigators. The results of surveys in the Kratovo-Zletovo area and analyses of stone assemblages from several archaeological sites of the Amzabegovo-Vršnik culture point to a system of local supply for stone tools used by the local communities. The aim of this paper is to draw attention to areas abundant in lithic raw materials and suggest that they were local sources for the production of stone artefacts in the Amzabegovo-Vršnik culture in Neolithic Macedonia.
\end{abstract}

IZVLEČEK - Kljub temu, da je bilo na prostoru Republike Makedonije izkopano veliko število neolitskih najdišč, so kamnita orodja iz teh najdišč še vedno slabo poznana, ker ponavadi niso pritegnila zanimanja raziskovalcev. Rezultati terenskih pregledov na območju Kratovo-Zletovo in analize zbirov kamnitih orodij iz številnih arheoloških najdišč kulture Amzabegovo-Vršnik kažejo na sistem lokalne preskrbe s surovinami. V članku opozarjamo na območja, bogata s kamnitimi surovinami, in predlagamo, da so le-ta predstavljala lokalne vire surovin pri proizvodnji kamnitih orodij v kulturi Amzabegovo-Vršnik.

KEY WORDS - Neolithic; Amzabegovo-Vršnik; Macedonia; raw materials; stone tools

\section{Introduction}

The Kratovo-Zletovo palaeo-volcanic area (Fig. 1) in the eastern part of the Republic of Macedonia is known as a region abundant in various types of rocks and minerals. It covers an area of $970.1 \mathrm{~km}^{2}$ and has been the subject of various investigations due to its polygenetic landscape (Serafimovski 1993; Arsovski 1997; Boev, Yanev 2001; Milevski 2005; 2010). The geomorphic features of this region, combined with the presence of prehistoric archaeological sites, require detailed surveys and research of the raw materials found in the stone assemblages in some of the excavated archaeological sites which are in, or are near, this area. Exploring the origin of the raw material that might have been used in the production of stone implements at the Neolithic archaeological sites like Amzabegovo (Korošec, Korošec 1973; Gimbutas 1976), Rug Bair (Sanev 1975; Dimitrovska 2011b; Dimitrovska, Boev 2012), Alin Dol (Zdravkovski, Šurbanovska 1983.111-123),
Vršnik (Garašanin, Garašanin 1961.7-40; Grbič 1954.115; Gockova-Slavska 1955.19), Grlo (Nacev 2009.8), and Grnčarica (Nacev 2009); or Eneolithic archaeological sites such as Bogoslovski Kamen ( $\mathrm{Na}$ cev 2009.5), Burilčevo (Nasteva 1989.49; Sanev 1961), St. Atanas (Atanasova 2010), Grad-Delčevo (Kolištrkoska Nasteva 2006.38-53), Cocev Kamen (Dimitrovska 2010b) and Viničko Kale (Dimitrovska 2011a), leads to the issue of the system of local supply of stone tools in Amzabegovo-Vršnik culture.

The raw material from Amzabegovo and Rug Bair

Amzabegovo-Vršnik culture (Garašanin 1979.79212) was spread across the eastern part of the Republic of Macedonia, including the middle and northern part of the country (Sanev 1995), and territorially overlapped with the Kratovo-Zletovo region. For 
millennia, the environment, which is abundant in volcanic rocks and minerals, provided the prehistoric inhabitants of the region and its immediate periphery with access to various resources needed in the manufacture of stone tools.

A thorough analysis of the raw material used in the production of stone tools was performed on material from two archaeological sites pertaining to the Amzabegovo-Vršnik cultural group: Barutnica, the eponymous site of this culture, and Rug Bair (Fig. 5). A common feature of Amzabegovo and Rug Bair is the presence of serpentinite, volcanic rocks of andesite and basalt, and sandstones from which the large majori-

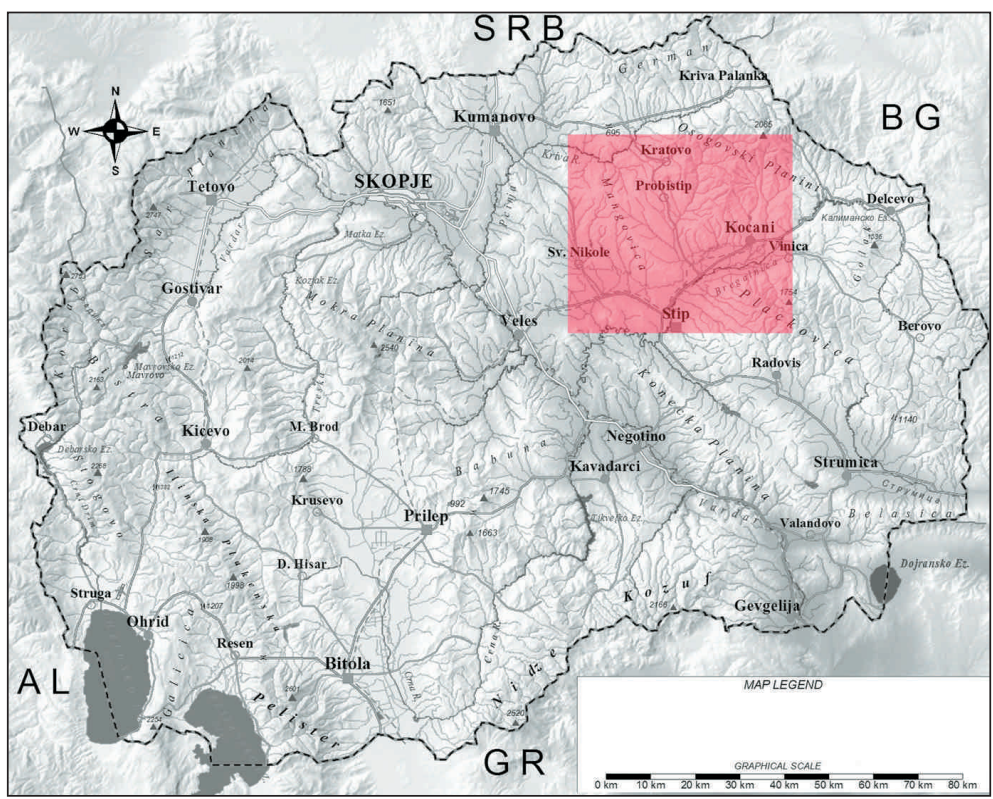

Fig. 1. Kratovo-Zletovo region. ty of the ground and abrasive stone tools at both sites were produced. The investigation confirmed that most of the artefacts from these sites were made of a raw material of local provenance that the inhabitants were able to collect near the sites (Waide 1976; Dimitrovska 2011b). The deposits of raw materials found in the lithic assemblages from Rug Bair are (even today) still accessible on the surface near the site (Dimitrovska, Boev 2012). The immediate proximity of Rug Bair and Amzabegovo (16km distance), and the similarity in the stone assemblage raises the question of whether it is possible that the quarrying of local resources was carried out in the same region and that these two Neolithic communities collected raw material in the same place (Fig. 2).

The most telling feature regarding the local origin of the raw material sources at Amzabegovo and Rug Bair is the use of serpentinite (Fig. 3). When the raw material at Amzabegovo was examined, the authors determined a big percentage of stone tools made from so-called 'green stone', from outcrops on the slopes of Mt. Bogoslovec. The green stone at Amzabegovo was described as rock consisting of minerals with the highest percentage of serpentine and jade, with intrusions of asbestos (Smoor 1970). The term 'green stone' can refer either to serpentines which are rocks made up of serpentine; jadeite and nephrite, which are the minerals described in the Amzabegovo assemblage under the term 'real jade', or eventually could be the green schist available in the Kratovo-Zletovo region (Dimitrovska 2011b). Nephrite is confirmed in the Neolithic stone assemblages in neighbouring countries, with an attempt to define a so-called 'nephrite culture' in the Balkans (Kostov 2005). It is not disputed that some samples of Amzabegovo might be made of nephrite acquired by importation, trade or exchange. It is also possible that nephrite is of local origin, an assumption that needs to be proven with field research.

According to the excavators, 'green stone' was also found in the assemblage at Rug Bair (Sanev 1975). The microscopic analysis of the samples from this site showed that the serpentine was of local provenance (Dimitrovska, Boev 2012), possibly originating from Mt. Bogoslovec. Because no petrographic analyses were performed during past examinations, this new information on the provenance of the Rug Bair material raises many questions regarding the similarity of the raw material at both sites and the system of local supply for the other AmzabegovoVršnik sites.

\section{Primary deposits of raw material}

A more comprehensive approach to studying the local supply of stone tools in Amzabegovo-Vršnik culture will be possible when the analyses of chipped

\begin{tabular}{|cc|}
\hline Amzabegovo & Rug Bair \\
\hline$\cdot$ jasper & $\cdot$ jasper \\
• calcedony & $\bullet$ calcedony \\
• flint/chert & $\bullet$ quartz \\
• opalit & $\bullet$ quartzite \\
• quartz?! & - tahilite \\
\hline
\end{tabular}

Fig. 2. Raw material for chipped stone tools. 


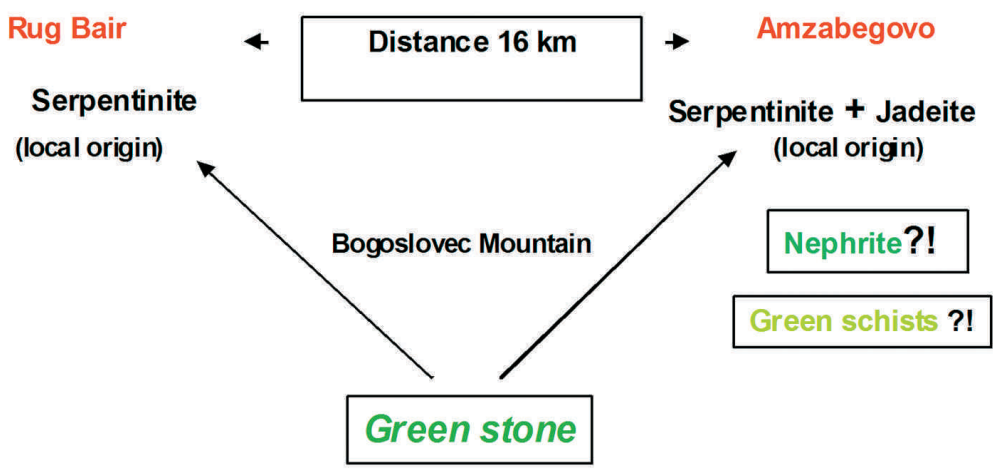

Fig. 3. Raw material for ground and abrasive tools at Amzabegovo and Rug Bair.

stone industry from the archaeological sites of Grnčarica, St. Atanas and Cocev Kamen have been completed. In relation to the stone industry, we can make the assumption that the supply of raw materials was probably local, due to the fact that sources of used types of rock have been confirmed in the vicinity.

Grnčarica is a single layer Early Neolithic site, where the surface deposits of raw material (chalcedony) are found on the outskirts of the site. This is the only Neolithic site where it has been confirmed that the raw material in the field is compatible with the raw material in the chipped stone assemblage $\mathbf{1}(\mathrm{Na}$ cev 2009). A large array of various raw materials was used in the production of chipped stone tools, including opalised white tufa. This raw material can be collected in the vicinity of the settlement at Strmoš, where an operational mine is still located. Its main activity is mining and processing opalised white tuff, quartzite and dolomite. Tools of opalised tuff have been found at Rug Bair (Dimitrovska 2011b), which allows the assumption that perhaps the inhabitants of these two settlements collected raw material for their stone tools from the same place.

The Eneolithic sites at St. Atanas and nearby Burilčevo are located in the region of Češinovo-Spančevo near the 'Opalite' mine, which is still operational today and produces opal, agate, chalcedony and opalised wood. Tools made from these materials were found during excavations at the aforementioned sites (Nasteva 1989; Atanasova 2010.9-14). The results of the investigation bring us very close to resolving the problem of the identification of local supplies of stone tools in the Eneolithic period. Consi- dering the number of prospected and excavated sites in the vicinity (Arheološka karta 1996), in the future it will be possible to connect the products of this mine with the stone assemblages from Neolithic settlements, specifically those belonging to Amzabegovo-Vršnik culture.

Cocev Kamen is an archaeological site with a span of periods, from the Neolithic to the late Middle Ages, when the region was settled. The surface finds of grey chalcedony of extremely high quality used for chipped stone tools (Dimitrovska 2010b.35-36; Milevski, Dimitrovska 2011) overlap with the area of the 'Silex' mine $5 \mathrm{~km}$ distant, which is still in use and produces various non-metals (Fig. 4). The abundance of cores, rejuvenation artefacts and waste, indicate the existence of a workshop at this same location. It is also possible that stone tools were made within the settlement and that the mine was a source of the materials used.

The map of excavated Eneolithic and Neolithic sites in Eastern Macedonia between Kratovo-Zletovo area and Bregalnica River shows their locations near or within the range of mines which are still active producing non-metals (Fig. 5). The existence of primary deposits of some types of raw material is further evidence that Neolithic communities living in this region
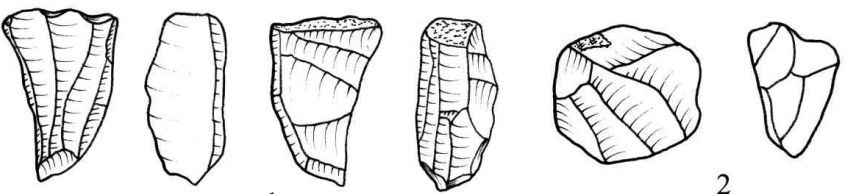

2

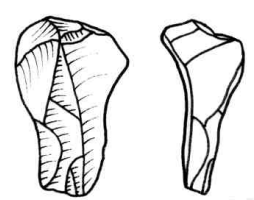

4
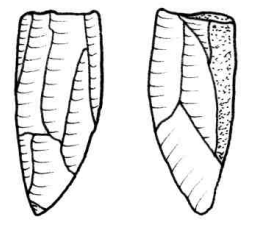

5

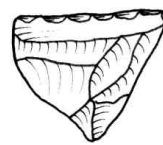

3

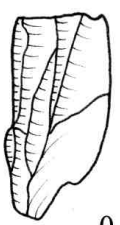

0
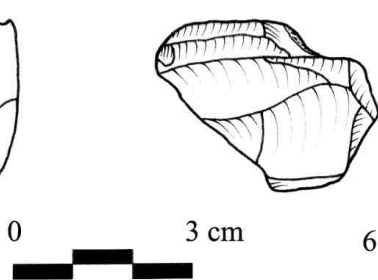

$3 \mathrm{~cm}$

Fig. 4. Cocev Kamen (Neolithic/Bronze Age), surface finds from chalcedony (drawing $V$. Dimitrovska, after Dimitrovska, Milevski 2011.Fig. 6). See legend: 1 double platform pyramidal core for flakes and blades; 2, 4, 6 rejuvenation flakes; 3, 5 single platform pyramidal core for blades.

1 Personal examination of the stone assemblage by the author. 
exploited local resources. This assumption should be further verified in the field and compared with the stone assemblages from archaeological excavations. Also, these factors show a strong need for the further study of the system of Eneolithic and Neolithic settlements that could have played the role of consumer, but also supplying centers for stone materials. A detailed study could contribute to identifying local resources for stone tools, as well as the identification of mines and Amzabegovo-Vršnik workshop sites.

\section{Balkan flint from Macedonia}

In the chipped stone collections from Neolithic sites in the Republic of Macedonia, we should emphasise the presence of chalcedony of a yellow-brown or honey colour with sporadic whitish spots that is very well-know and is often referred to as 'Balkan flint' (Kaczanowska, Kozłowski 2008.12; Kozłowski, Koztowski 1984; Voytek 1985).

Artefacts made of Balkan flint were found at Early Neolithic sites of the Starčevo-Körös-Cris culture (Bonsall 2008.271), at sites within the Iron Gate along the Danube (Boric 2007.36, 39), at some Croatian (ك̌ošić Klindžić 2010) and Bulgarian sites (Gatsov 1993; Gurova 2008), at Early and Middle Neolithic sites in Serbia (ك̌arić 2002) and along the River Pindos in Greece (Perlès 2001).

The common feature of all the Neolithic chipped stone assemblages from Amzabegovo-Vršnik culture that have been examined is the presence of artefacts made from Balkan flint. Their shape shows signs of prepared-core techniques, and the artefacts can mostly be defined as bilateral retouched blades or end scrapers on bilateral retouched blades, with semi-abrupt retouch, sometimes with a silica shine (Fig. 7). Balkan flint in the Republic of Macedonia was discovered at archaeological sites at Na Breg (North Macedonia), Zuniver (Central Macedonia), Mramor (Central Macedonia) and Tumba Madžari (North Macedonia). According to researchers, except in the case of Mramor, which is Late Neolithic (Jovčevska 1993), the chipped stone assemblages from Na Breg (Zdravkovski 1988), Zuniver (Arheološka karta 1996) and Tumba Madžari (Sanev 1988) derive from the middle Neolithic layers that are contemporary with Amzabegovo (Elster 1970) and Rug Bair, where the presence of this raw material was also confirmed (Dimitrovska 2011b).

We have to question the assumption that the production of 'Balkan flint' tools took place outside the village, because many Neolithic sites in the territory of the Balkans suggest that artefacts were made within settlements. Pieces of Balkan flint with cortex, flakes, blades and waste found together in many of the discussed sites, and especially at Rug Bair, are additional evidence in support of this hypothesis. 20 Balkan flint artefacts were discovered at Amzabegovo, and 11 such specimens were documented at Rug Bair. 6 of these artefacts were identified as tools, including a typical crested blade and two pieces considered lithic waste (Fig. 6). The small collection of Balkan flint is completed with two unretouched flakes, one bearing the cortex on less than $50 \%$ of its dorsal side (Dimitrovska 2011b).

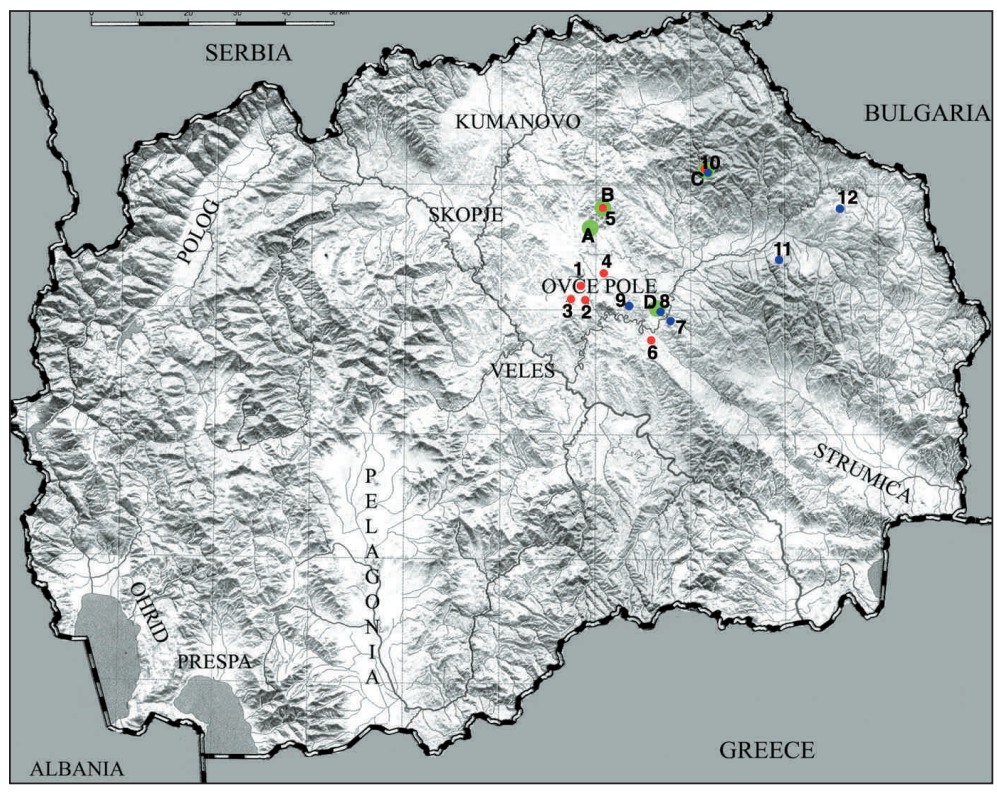

2 Map from Naumov 2009.Fig. 1.3, 4
Fig. 5. Excavated Neolithic and Eneolithic sites in East Macedonia and the location of possible prehistoric sources of non-metals 2 . See legend: red (Neolithic sites); blue (Eneolithic sites); green - active natural resources for non-metals. 1 Rug Bair. 2 Amzabegovo. 3 Grlo. 4 Alin Dol. 5 Grnčarica. 6 Vršnik/Tarinci. 7 Burilčevo. 8 St. Atanas. 9 Bogoslov Kamen. 10 Cocev Kamen. 11 Viničko Kale. 12 Grad-Delčevo. A Mine 'Strmoš (Probištip). B Grnčarica. C Mine 'Silex' (Kratovo). D Mine 'Opalit' (Češinovo-Spančevo). 


\section{Secondary deposits of raw material}

Regarding the fact that East Macedonia is characterised by an abundance and diversity of raw materials, a survey was conducted to find and record new Palaeolithic and Mesolithic sites. During the prospecting, no open air sites were discovered in the Kratovo-Zletovo micro region, which is considered one of the richest ore zones in Macedonia (Filipovski 1974). The survey confirmed the presence of secondary deposits rich in silicate. A survey of 7 locations revealed the distribution of local materials such as opal, opalised wood, quantities of pebbles and cobbles of jasper, quartz and quartzite, as well as andesite and basalt of local origin. A large concentration of jasper, vulcanite and metamorphites fragments which derive from the Neokazi jasper quarry was also found (Šalamanov-Korobar 2006). Since the results showed no traces of stone production, the question of local supply of raw materials and the correlation with the neighbouring sites in the Neolithic, will remain open. The lack of Palaeolithic, Mesolithic, and Early Neolithic sites in the Republic of Macedonia excludes the possibility of discussing issues related to evolutionary trends of artefacts and a comparison of raw stone materials used at Amzabegovo-Vršnik sites (Dimitrovska 2010a).

\section{Conclusion}

The Kratovo-Zletovo palaeo-volcanic area located within the territory of the Amzabegovo-Vršnik culture has been known since prehistory as a region abundant in lithic raw materials. It is clear from the situation in the field that in the Neolithic period, an abundance of raw materials could be found and exploited in the wider area around the sites, making them available to other prehistoric and historical cultures in this region. Some sources of raw material were located relatively close to the sites, and the rocks and minerals could be collected from primary or secondary deposits.

Mines and quarries of non-metals in Eastern Macedonia have not been the focus of scientific inquiry of Macedonian archaeology, unlike in neighbouring countries (Bogosavljević-Petrovic 1999; 2005). The reasons for reconsidering their modern function are indications leading to the resolution of the problem of identifying stone mining and workshop sites. This

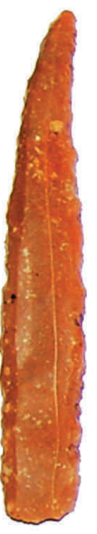

1
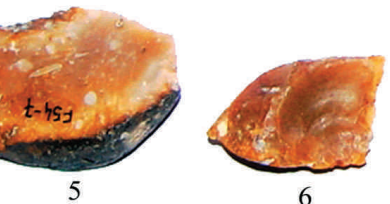

3

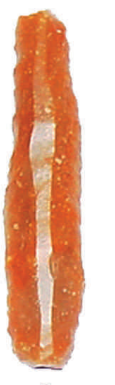

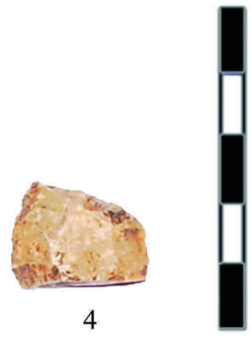
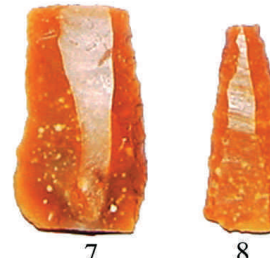

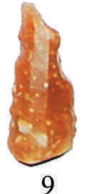

9

Fig. 6. Balkan flint from the Republic of Macedonia (photo V. Dimitrovska). See legend. 1 Bilaterally retouched blade (Tumba Madžari). 2, 7 Bilaterally retouched blade with fragmented distal part. 3 Double end scraper on bilaterally reblade. 4 End scraper with fragmented proximal bilaterally retouched blade. 9 Perforator on bilaterally etouched blade (Rug Bair).

connection will permit us to establish the relations between the raw material found at the archaeological sites pertaining to Amzabegovo-Vršnik culture and the local sources in their vicinity.

These mines and quarries can provide answers to many questions relating to the identification of mining and workshop sites in this region in terms of the local supply of raw materials for stone tools, especially in prehistoric periods such as the Neolithic. The study of these resources can provide information about the socio-economic structure of the settlements and the level of technological development within certain settlements, which can reveal locations and parallels in the prehistoric stone industry in the Republic of Macedonia in relation to some assemblages in Serbia (Šarić 2002.11-26; 2006a.197-210; 2006b.9-45) and Bulgaria (Gatsov 1993; Gurova, Nachev 2008.29-35) which have already been described.

According to some researchers, the issue of Balkan flint is very important, since it was listed among the elements that characterise the earliest processes of Neolithisation in the Balkans (Gurova 2008; 2009). Indications of the existence of primary resources of certain raw materials for stone tools in Eastern Mace- 

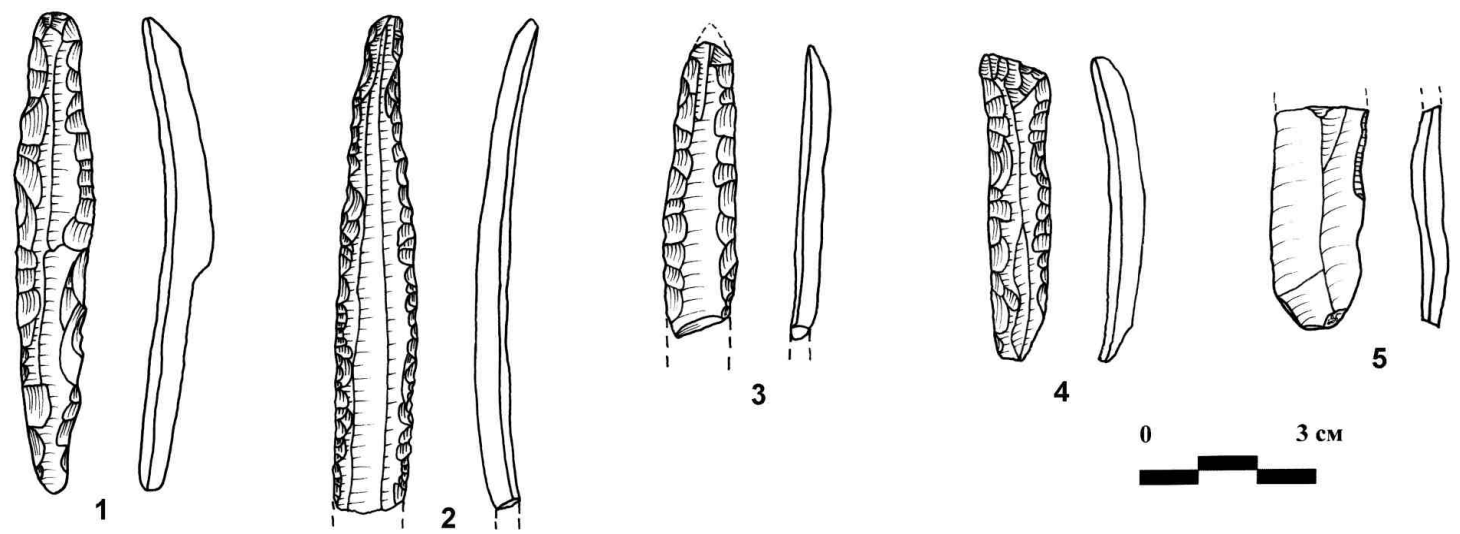

4

Fig. 7. Balkan flint from the Republic of Macedonia (drawing V. Dimitrovska). 1 Zuniver. 2, 5 Tumba Madžari. 3, 4 Mramor.

donia, in particular mines and quarries for non-metals like Češinovo-Spančevo, give rise to the possibility that Balkan flint found at Neolithic settlements of the Amzabegovo-Vršnik culture was not imported, but of local provenance. This has already been confirmed in the case of Balkan flint artefacts from Amzabegovo (Smoor 1976), where a comparison of examples based on macroscopic examination was made with Romanian and Bulgarian flint, which has inclusions of silica or nummulites (Elster 1976.265). The Geological Map of the Republic of Macedonia combined with field prospecting and the existence of primary deposits of raw materials that could be collected in the vicinity of Neolithic settlements $\left(\mathrm{JO}^{-}\right.$ vanovski et al. 2004.111-141; Makreski et al. 2004. 171-184) allow us to test and subsequently confirm or disprove their local origin, following future surveys in the field.

At this stage of the investigation, it is very hard to reconstruct the mechanism by which raw stone materials used in manufacturing stone tools were acquired, transported and distributed through Amzabego-
vo-Vršnik settlements. Raw material documented in Neolithic stone assemblages in the Republic of Macedonia refers to the system of supply, complemented by the existence of similar material of local provenance. The primary and secondary deposits confirmed around the sites by the field survey allow us to propose that certain regions were possible local sources for the production of stone artefacts in Amzabegovo-Vršnik culture from Neolithic Macedonia.

$$
\text { ACKNOWLEDGEMENTS }
$$

This paper is dedicated to the memory of Nedeljko Đordević, geologist and petrologist, with whom I shared many field prospecting, excavations, discussions and studies about the lithic material. I would also like to thank the City Museum of Štip for providing material from the excavation of the site at Rug Bair, as well as colleagues in the Republic of Macedonia who gave me access to prehistoric stone assemblages. The studies of raw material were made possible with the help of the Faculty of Natural and Technical Sciences, Štip, Republic of Macedonia.

\section{$\therefore$}

\section{References}

Arheološka karta na Republika Makedonija (Archaeological map of the Republic of Macedonia) 1996. Tom 2. Makedonska Akademija na umetnostite i naukite. Skopje.

Arsovski M. 1997. Tectonic of Macedonia. Faculty of Geology and Mining. Stip.

Atanasova I. 2010. Kultnata plastika od eneolitskoto naogjalište Sv. Atanas - s. Spančevo, Kočansko. Biblioteka 'Iskra'. Kočani: 9-14.
Boev B., Yanev Y. 2001. Tertiary magmatism within the Republic of Macedonia: A review. Acta Volcanologica 13 (1-2): 57-71.

Bogosavljević-Petrović V. 1999. Ka problemu identifikacije rudničkih i radioniičkih nalazišta kamenih sirovina u periodu neolita i eneolita. Starinar 49: 155-166.

2005. Praistorijski rudnici na centralnom Balkanu. Zbornik Narodnog muzeja XVIII(I): 79-113. 
Bonsall C. 2008. The Mesolithic of the Iron Gates. In G. Bailey, P. Spikins (eds.), Mesolithic Europe. Cambrige University Press, Cambrige: 238-279.

Borić D. 2007. Mesolithic-Neolithic Interactions in the Danube Gorges. In J. K. Kozłowski, M. Nowak (eds.), Mesolithic-Neolithic Interactions in the Danube Basin. BAR IS 1726. Archaeopress, Oxford: 31-45.

Dimitrovska V. 2010a. Prilog kon vrednuvanjeto na neolitskiot litički material. Macedoniae Acta archaeologica 19: 33-47.

2010b. Cocev kamen, nešto povekje od samo obična karpa. Kulturen život 1-2: 30-37.

2011a. Kulturen segment od eneolitskiot period period na Istočna Makedonija. Katalog od izložba. Muzej 'Terakota'. Vinica: 2-3.

2011b. Industrija okresanog $i$ glačanog kamena sa neolitskog lokaliteta Rug Bair u Gorubincima, $u$ širem regionalnom kontekstu. Unpublish MA thesis. Philosophical faculty, University of Beograd. Beograd.

Dimitrovska V., Boev B. 2012. Petrologic, Morphologic and Functional Analysis of Ground and Abrasive Stone Tools from Rug Bair, Ovče Pole Valley. Geologica Macedonica 25(1): 37-52.

Elster E. 1976. The chipped stone industry. In M. Gimbutas (ed.), Neolithic Macedonia. As reflected by Excavation at Anza. Southeast Yugoslavia. The regents of the University of California. Los Angeles: 257-278.

Filipovski B. 1974. Geološki sostav na SR Makedonija. In Geološki sostav i rudno bogastvo na Makedonija. 'Nova Makedonija'. Skopje: 53-72.

Garašanin M., Garašanin D. 1961. Neolitskata naselba Vršnik kaj selo Tarinci. Zbornik na Štipski naroden muzej II: 7-40

Garašanin M. 1979. Centralnobalkanska zona. In A. Benac (ed.), Praistorija Jugoslovenskih zemalja II, Neolitsko doba. Akademija Nauke i Umetnosti Bosne i Hercegovine. Sarajevo: 79-212.

Gatsov I. 1993. Neolithic chipped stone industries in Western Bulgaria. Institute of Archaeology. Jagellonian University. Krakow.

Gimbutas M. 1976. Neolithic Macedonia. As reflected by Excavation at Anza, Southeast Yugoslavia. Los Angeles: The regents of the University of California. Los Angeles.
Gockova-Slavska P. 1955. Probno iskopuvanje na lokalitetot 'Vršnik'. Glasnik na Muzejsko-konzervatorskoto društvo na NR Makedonija 1-2: 19-21.

Grbić M. 1954. Arheološki naogjališta vo Makedonija. Glasnik na makedonskoto konzervatorsko društvo I-9: 100142.

Gurova M. 2008. Towards an understanding of Early Neolithic populations: a flint perspective from Bulgaria. In M. Budja (ed.), 15th Neolithic Studies. Documenta Praehistorica 35: 111-129.

2009. Kremichnia faktor $\mathrm{v}$ neolitizacionija debat. B: LAUREA. In B. Petrunova, A. Aladzov and E. Vasileva (eds.), In honorem Margaritae Vaklinova. Book II. Sofia: 1-14

Gurova M., Nachev Ch. 2008. Formal Early Neolithic flint toolkits: archaeological and sedimentological aspects. In R. I. Kostov, B. Gaydarska and M. Gurova (eds.), Geoarchaeology and Archaeomineralogy. Proceedings of the International Conference, 29-30 October 2008. Publishing House 'St. Ivan Rilski', Sofia: 29-35.

Jovanovski G., Boev B., Makreski P., Najdoski M. and Mladenovski G. 2004. Minerals from Macedonia, silicate varieties and their localities - identification by FT IR Spectroscopy. Bulletin of the Chemists and Technologists of Macedonia, 22(2): 111-141.

Jovčevska T. 1993. Kukjata od horizont I vo neolitskata naselba 'Mramor' kaj Čaška. Macedoniae acta archaeologica 13: 3-40.

Kaczanowska M., Kozłowski J. K. 2008. The Körös and the early Eastern Linear Culture in the northern part of the Carpathian basin: a view from the perspective of the lithic industries. Acta Terrae Septemcastrensis VII: 9-38.

Kolištrkoska Nasteva I. 2006. Eneolitskoto naogjalište vo delčevsko. Macedoniae Acta archaeologica 17: 38-53.

Korošec P., Korošec J. 1973. Predistoriskata naselba barutnica. DISS. Arheološko društvo na Makedonija. Prilep.

Kostov R. I. 2005. Gemmological significance of the prehistoric Balkan 'nephrite culture' (cases from Bulgaria). Annual of the University of Mining and Geology, Geology and Geophysics 48(1): 91-94.

Kozłowski J. K., Kozłowski S. K. 1984. Chipped Stone Industries from Lepenski Vir. Preistoria Alpina 19: 259-294.

Makreski P., Jovanovski G., Kaitner B. , Stafilov T. and Boev B. 2004. Minerals from Macedonia. The Dependance 
of Quartz and Opal Color on Trace Element Composition - AAS, FT IR and Micro-Raman Spectroscopy Study. Bulletin of the Chemists and Technologists of Macedonia 23: 171-184.

Milevski I. 2005. Basic features of palaeovolcanic relief in the western part of Osogovo massif. Geographical review 40: 47-67.

2010. Geomorphological Characteristics of Kratovo-Zletovo Palaeovolcanic Area. Proceedings of the XIX CBGA Congress, Thessaloniki, Greece. Scientific Annals. Special volume 99: 475-482.

Milevski I., Dimitrovska V. 2011. Geomorfološki i geoarheološki karakteristiki na Cocev Kamen. Geografski razgledi (44-45): 5-19.

Nacev T. 2009. Arheološki lokalitet Grnčarica, s. Krupište. Trite Keramitki - rezultati od zaštitnite arheološki istražuvanja Zletovica 2007-2009. Štip: 4-10.

Nasteva I. 1989. Pilavo-Burilcevo, eneolitska i helenisticka naselba. Arheološki pregled 28: 49.

Naumov G. 2009. Patterns and Corporeality: Neolithic Visual Culture from the Republic of Macedonia. BAR IS 1910. Archaeopress. Oxford.

Perlès C. 2001. The Early Neolithic in Greece. The first farming communities in Europe. Cambridge World Archaeology. Cambridge University Press. Cambridge.

Sanev V. 1961. Izveštaj od arheološkite rekognosciranja vo Istočna Makedonija. Zbornik na Narodniot muzej za Štipskiot kraj II. Štip.

1975. Neolitskata naselba Rug Bair kaj s. Gorobinci. Zbornik na Štipski naroden muzej IV-V: 203-246.

1988. Neolitsko svetilište od Tumba vo Madžari, Skopsko, preliminarno soopštenie od iskopuvanjata vo 1981. Macedoniae acta archaeologica 9: 9-30.

1995. Neolitot i neolitskite kulturi vo Makedonija. $\mathrm{Ci}$ vilizacii na počvata na Makedonija 2: 21-46.
Serafimovski T. 1993. Structural-metallogenic features of the Lece-Chalkidiki zone: types of mineral deposits and distribution. University 'Sv. Kiril i Metodij' Skopje. Faculty of Mining and Geology-Stip, Geological Department. Štip.

Smoor J. B. 1976. Polished stone tools. In M. Gimbutas (ed.), Neolithic Macedonia. As reflected by Excavation at Anza, Southeast Yugoslavia. The regents of the University of California, Los Angeles: 178-184.

Šalamanov-Korobar Lj. 2006. Rekognosciranje na paleolitsko-mezolitski lokacii vo Makedonija - 2001. Macedoniae acta archaeologica 17: 9-12.

Šarić J. 2002. Stene kao materijal za izradu okresanih artefakata u ranom i srednjem neolitu Srbije. Starinar 52: 11-26.

2006a. Kamene alatke koriščene u izradi okresanih artefakata tokom neolita na tlu Srbije. Glasnik Srpskog arheoškog društva 22: 197-210.

2006b. Typology of chipped stone artefacts in the Early and Middle Neolithic in Serbia. Starinar 56: 9-45.

Šošić Klindžić R. 2010. The supply system of siliceous rocks between the Drava, Sava and Danube rivers during the Starčevo culture. In M. Budja (ed.) 18th Neolithic Studies. Documenta Praehistorica 38: 345-356.

Voytek B. A. 1985. The Exploitation of Lithic Resources In Neolithic Southeast Europe. University of California. Berkeley.

Waide W. 1976. Source areas of lithic materials. In M Gimbutas (ed.), Neolithic Macedonia. As reflected by $E x$ cavation at Anza, Southeast Yugoslavia. The regents of the University of California, Los Angeles: 279-282.

Zdravkovski D. 1988. Istražuvanje na lokalitetot 'Na Breg', selo Mlado Nagoričane. Macedoniae acta archaeologica 9: $43-63$.

Zdravkovski D., Šurbanovska M. 1983. Izveštaj od zaštitnoto istrazuvanje na HEC 'Mavrovica' vo s. Nemanjici, Svetinikolsko. Zbornik na arheološki muzej na Makedonija $X-X I$ : 111-123. 